\title{
Young people at the margins in Pretoria Central: Are the faith-based organisations making a difference?
}

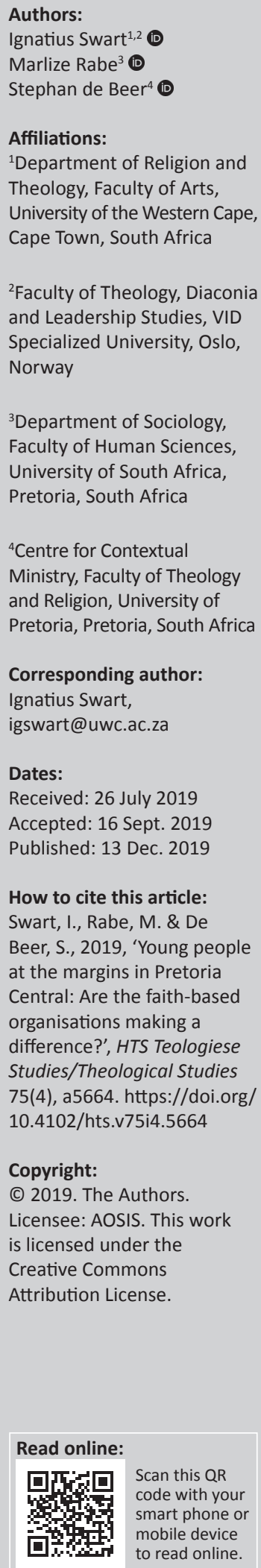

The authors' recent case study work in Pretoria Central as part of the international research project 'Youth at the margins' (YOMA) constitutes the focus of this article. From this vantage point, the authors offer a presentation of their research findings in order to ultimately answer the question 'to what extent the faith-based organisations (FBOs) are making a difference in the lives of young people at the margins in this particular case study locality (Pretoria Central)'. The article begins by contextualising the lives of young people in Pretoria Central against the backdrop of far-reaching socio-economic, demographic and religious change in the area since the end of the apartheid era. After explaining the case study methodology and offering a brief profile of the research participants, the discussion then proceeds with a more detailed discussion of distinctive aspects of the case study findings. In the conclusion, the authors argue that the answer to the article's guiding question seems to be a negative one when the reality of young people's seemingly permanent structural exclusion is considered. At the same time, this verdict does not withhold them to also conclude with appreciative remarks about the role that churches and FBOs of the non-governmental organisation (NGO) type are playing with respect to marginalised young people in Pretoria Central.

Keywords: Young People at the Margins; FBOs; churches; Pretoria Central; social cohesion; exclusion; basic survival needs.

'The place is very unhealthy, it is very old ... You can have more than 20 people in the house. Imagine. That's why this is a slum area.' (Participant in focus group interview with male and female participants, 15-19 years old, Salvokop)

\section{Introduction}

The authors' recent case study work in Pretoria Central as part of the international research project 'Youth at the margins: A comparative study of the contribution of faith-based organisations (FBOs) to social cohesion in South Africa and Nordic Europe' (YOMA) constitutes the focus of this article. By way of brief recapitulation, YOMA was a research undertaking formally conducted during 2013-2016 by a group of South African and Nordic researchers. At its core, the project involved a case study research in selected localities both in South Africa and Finland and Norway, seeking to explore the manner and extent to which FBOs were touching the lives of the so-called marginalised youths in the selected localities ${ }^{1}$ (Swart 2018:1; see also Swart 2013). With this exploration in mind, furthermore, a threefold conceptual focus was identified that would determine the theoretical and thematic scope of the project:

- A focus on 'marginalised youth' or 'youth marginalisation' as defined by the internationally accepted concept of NEET - an acronym for 'young people not in education, employment and training' (Swart 2018:3, 5; cf. Swart 2013:5-8).

- A focus on 'faith-based organisations' as religious agency, in accordance with a working definition by Gerard Clarke and Michael Jennings that understands an FBO as any organisation that derives inspiration and guidance for its activities from the teachings and principles of a particular faith tradition or from a particular interpretation or school of thought within that

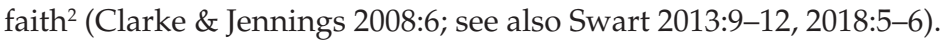

- A focus on 'social cohesion' understood as a value-oriented and politically oriented concept through which faith-based action and practice could be evaluated for its contribution to the

1.In total, six case studies were conducted: one each in Finland and Norway and four in South Africa. In turn, the case studies all form part of separate case study chapters standing in the centre of a forthcoming anthology entitled Stuck in the Margins: Young People and Faith-Based Organisations in South African and Nordic Localities.

2.Faith-based organisations (FBOs) could in this sense, for example, include churches, mosques and also faith-based NGOs operating as social welfare and development actors in civil society.

Note: Faith-Based Organisations, sub-edited by Nadine Bowers du Toit (Stellenbosch University), Vhumani Magezi (North-West University) and Elisabet le Roux (Stellenbosch University). 
creation of societal conditions that ... significantly enhance young people's opportunities, in particular those who find themselves in marginalised and vulnerable positions for whatever reason, for civic participation in all spheres of life: social, cultural, economic, educational and political (Swart 2013:13; cf. Angell \& De Beer 2019).

This article, against the above backdrop, seeks to make a contribution to the special collection 'Does faith matter? Exploring the role of faith-based organisations as civil society actors' by drawing on the YOMA project work. More specifically, we were the three members of the project team responsible for executing the case study research in Pretoria Central, which constituted one of the four South African case studies in the project. ${ }^{3}$ From this vantage point, we want to offer a presentation of our research findings in order to ultimately answer the question, 'to what extent the FBOs are making a difference in the lives of young people at the margins in our particular case study locality (Pretoria Central)?'.

We start the discussion by contextualising the lives of young people in Pretoria Central against the backdrop of far-reaching socio-economic, demographic and religious changes in the area since the end of the apartheid era in the early to mid1990s. After explaining our case study methodology and offering a brief profile of the research participants, we proceed with a more detailed discussion of the case study findings. We begin with an account of our young interviewees' experiences of Pretoria Central as a place of considerable hardship and the resultant expressions of hope and despair that emanated from such experiences. From this vantage point of deepened contextual insight, our focus shifts to the pertinent concern, that is, the role of FBOs in the lives of the young people whom we interviewed. This is done in two separate sections: firstly, we discuss the perceptions and expectations of FBOs expressed by our young interviewees amidst their experiences of hardship and, secondly, we examine the meeting of basic survival needs as a dominant mode of FBO involvement with the young people. Finally, we bring the discussion to an end by more pertinently returning to our guiding question, answering on the basis of the different aspects of our research findings, 'to what extent the FBOs can be considered as change agents that are making a difference in the lives of marginalised young people in Pretoria Central?'.

\section{Young people in Pretoria Central}

Pretoria Central has been changed dramatically from being an almost exclusively white community at the end of the apartheid era in 1994 to a cluster of neighbourhoods predominantly occupied by black people today.

Furthermore, although the population of Pretoria Central was always a more youthful one, often accommodating young families until they were established enough to buy a house in the suburbs, recent statistics have shown that Pretoria Central has become an increasingly young

3.The other South African case studies were conducted in the eMakhazeni Loca Municipality (Mpumalanga province), Franschhoek (Western Cape province) and Riverlea (on the outskirts of Johannesburg, Gauteng province). community, with the median age being 25 years (see StatsSA 2011, n.d.; Wazimap n.d.).

Yet another significant statistic is that approximately only $20 \%$ of the population of Pretoria Central originally are from within the Gauteng province in which Pretoria is located, with $80 \%$ of the population having migrated from elsewhere at some point in time (cf. StatsSA 2011, n.d.; Wazimap n.d.). Pretoria Central thus presents itself at least initially as a place of promise for many. This could be explained by the strategic location of the City of Tshwane, with Pretoria Central at its core, as a significant part of the Gauteng City-Region, which is an economic powerhouse on the African continent. In addition, one may also consider favourable factors such as Pretoria Central's close proximity to three of the largest universities in the country, ${ }^{4}$ as well as the Department of Home Affairs' newly erected centre for newcomers to South Africa in Marabastad, on the edge of Pretoria Central (cf. Gauteng City-Region Observatory n.d.; Rabe, Swart \& De Beer 2019:166-168).

However, the large-scale economic disinvestment in Pretoria Central that coincided with South Africa's political transition to democracy in the early 1990s has rendered the expectation of economic opportunity in Pretoria Central rather illusionary for many (Rabe et al. 2019:167). Here, we particularly consider the way in which Pretoria Central has, since the early 1990s, presented 'arrival neighbourhoods' for large numbers of not only vulnerable young people, South African youths, ${ }^{5}$ but also transnational migrants, hoping to find alternatives or running away from abusive and desperate situations. While this group of vulnerable young people was initially comprised mostly of young men and boys living on the streets in places such as Sunnyside or Marabastad, towards the late 1990s and since 2000 the youths on the streets have increasingly included young women and girls as well (cf. De Beer \& Vally 2017:384; Moloko-Phiri, Mogale \& Hugo 2017:439-449).

It follows that for many young migrants, Pretoria Central has not delivered the desired results. Their lives are instead characterised by an ongoing precariousness that leaves them particularly vulnerable to exploitation, exclusion and risky life styles as reflected in the endemic substance addiction, the proliferation of child-headed households and the activities of a visible and well-established commercial sex work and human trafficking industry (cf. De Beer \& Vally 2015:14-15, 24-25, 2017:390; Mkansi 2012). For this group of young people, migration and mobility have clearly not translated into a better life, but have become part of a permanent survival strategy, as they move from one place to another, from one street corner to another, from one relationship to another, in order to survive (Rabe et al. 2019:167).

4.University of Pretoria, University of South Africa and Tshwane University of Technology.

5.These young people may often come from surrounding black townships or informal settlements. In other cases, they may come from further afield, noticeably rura areas where opportunities for work, education and training are few and far between. 
The reality sketched of Pretoria Central as a place where many young people suffer from a 'multiplicity of deprivations' (De Lannoy 2017:3) is well matched by statistical research, which suggests that more than half of the population of Pretoria Central may be unemployed (cf. StatsSA 2011, n.d.; Wazimap n.d.). We concede that this figure may be misleading as there are also large numbers of young people in Pretoria Central who are working and/or studying, and as occupants of one of the many apartments in the area could be considered to be relatively well-off. Nevertheless, this does not relativise the picture of precarious living conditions and life styles that we have sketched as the fate of a disturbing section of the young population that lives in present-day Pretoria Central.

\section{Faith-based organisations in a context of far-reaching religious change}

It becomes important to note in the light of the topical focus of our article that the profile of the faith-based sector in Pretoria Central has also changed dramatically as a result of the changing demography. In 1994, for example, there were only nine churches in the central part of Pretoria. These churches were all, with the exception of one, churches from traditional mainline (mostly white Reformed) denominations. Today, in the same area, a recent count found 57 churches, now predominantly independent Pentecostal and charismatic churches, with almost exclusively having black members (Ribbens \& De Beer 2017:5-7).

Churches, therefore, have diversified, with low percentages of white members and an overwhelming black membership that includes members from other African countries. For example, the Apostolic Faith Mission in Sunnyside offers worships in at least five languages, acknowledging the large number of Amharic-, French- and Portuguese-speaking people living in Pretoria Central. A former white, Afrikaans Seventh-Day Adventist Church became an Ethiopian Orthodox Church, and the former congregation of the Netherdutch Reformed Church is now a vibrant charismatic church led by a Ghanaian pastor. In terms of this everincreasing religious and ethnic diversification, it is important to mention that two new mosques were also built in Pretoria Central over the past 20 years, and the majority of Somali newcomers into Pretoria Central are Muslim believers (De Beer \& Smith 2019).

While most faith-based work in Pretoria Central was performed through local congregations before 1994, the post1994 period has witnessed the emergence of a number of strong and well-established NGO-type FBOs, such as Participate, Empower, Navigate (PEN n.d.), Tshwane Leadership Foundation (TLF n.d.) and the People Upliftment Programme (POPUP n.d.). Participate, Empower, Navigate (PEN) has always had a strong focus on children and the youth, and the TLF's focus on the most vulnerable people in the inner city made them reaching out to young girls on the streets and an increasingly young homeless population.
Non-governmental organisation-type FBOs have often played a leading role in incubating social responses to particular inner-city vulnerabilities in Pretoria Central that were not sufficiently addressed by the state. Examples of such responses include the Sediba Hope Medical Centre (n.d.), which was initially established to create HIV and AIDS support services in close proximity to local inner-city communities, but today provides much more comprehensive community-based health care; and Yeast City Housing (n.d.), a faith-based social housing company that evolved from the TLF and now manages over 1300 social housing units in the inner city.

\section{Methodology and profile of research participants}

Our research was aimed at developing an in-depth understanding of the contextual situation of marginalised youths in Pretoria Central and from this vantage point addressing two issues in particular: (1) the perceptions and expectations of marginalised youths regarding FBOs in this context and (2) the way in which religion and FBOs touched the lives of those young people. The research method was a case study that started with the researchers visiting various sites in Pretoria Central. One of the members of the research team (S.d.B.) had years of involvement with various organisations in Pretoria Central and he introduced the other members to various sites, such as houses of safety, shelters, and prominent churches providing homework facilities and/ or holiday programmes for school children.

Purposive sampling was used to gain access to research participants through youth workers and social workers. Care was taken to include participants who had experiences of and support from FBOs as well as people who had little or no contact with them, necessitating the use of different entry points for sampling, such as shelters, a community centre and a prominent park where tea and bread were distributed daily. Only one participant mentioned encounters with religious bodies that were not Christian, but he also had a long-standing involvement with Christian churches.

We conducted individual interviews with FBO workers, youth workers, clergy, a school principal and a government official at the national youth desk (hereafter referred to as resource persons). In total, 24 in-depth interviews were conducted with identified marginalised youths (even though four of them were somewhat older and one was 30 years old, we decided to include them because of their willingness to be interviewed).

All the individual and focus group interviews were conducted during 2015 and the beginning of 2016.

Three interviews were also conducted with focus groups: one with women only, one with men only and one with both young men and women. An additional focus group interview was held with youth workers working at an FBO. 
All interviews were conducted in English, a language in which all the research participants could express themselves fluently as it is widely used in urban areas in South Africa as a language of communication. The only exception was one individual interview with an Afrikaans-speaking youth and two interviews with resource people who preferred to speak in Afrikaans. All the youth participants were black people, except for one mixed race participant. The majority of the resource people and the clergy were black South Africans, while one Indian, one mixed race and four white South Africans also formed part of this group.

Of the 24 participants with whom individual interviews were held, 14 lived on the streets most days, 4 lived with family members, 5 lived in shelters or foster care homes and 1 was living in an informal dwelling with friends. Of the individual participants, 13 were men and 11 were women. Two of the women were pregnant at the time of the interviews. The participants in the female focus group lived in a shelter (some with their children), while the participants in the male focus group lived on the streets (there were no full-time shelters for men over the age of 18 years at the time of the research). In contrast, the participants from the mixed group (men and women) all lived with their families and, with the exception of one participant, were all in school. In the latter group, we interviewed male and female participants together as fewer participants were available and they all arrived at the same time for the interview (it was our third attempt to secure this interview). Five of the participants declared that they were addicted to Nyaope, ${ }^{6}$ although many more referred to their smoking habits. One participant was participating in a sponsored drug rehabilitation programme.

The divisions between us as researchers and the participants were stark. Aspects such as our formal educational levels, access to resources, racial identities and different lifestyles were dividing factors. Yet, these divisions also meant that certain participants narrated some of their experiences in detail, as they believed we understood nothing about their circumstances. However, certain participants also indicated that they were not willing to share certain aspects of their lives, as that was too painful and we respected their decisions. This was in line with the stipulated ethical guidelines, which included willing and informed consent and the right of participants to withdraw from the study at any time without any negative consequences. Respecting the wishes of the participants and using only pseudonyms in this article are examples of our commitment to follow general ethical standards for research. We obtained ethical clearance for this study from the University of South Africa before embarking on any fieldwork.

With the exception of one individual interview where detailed notes were made, all the interviews were audiorecorded and fully transcribed. The transcriptions together

6.Nyaope, also known as Whoonga in some South African communities, is a drug cocktil consisting of illit drugs such as methamphetamine, heroin and is a drug a cock tall consisting of illicit drugs such as methamphetamin 2014). As there as well as HIV antiretroviral medication (Grelotti et al. 2014). As there is no standardised recipe or method to mix the cocktail, the dosages may differ dramatically and may also contain a number of unknown substances. with field notes formed the basis of our thematic coding approach as described by Neuman (2003:441-445) and Babbie (2013:396-400).

\section{A place of hardship: Between hope and despair in Pretoria Central}

A thematic line pursued from the very start of this article relates to Pretoria Central as a place of hardship for many young people living there. From the vantage point of our participants' own articulation of their experience, some of the strongest viewpoints emerged from the focus group interview with male and female participants. One common aspect between the participants from this group (all from Salvokop), 15 and 19 years, was that they were all still attending school and living with their family members (except for one participant who had completed high school in the previous year and described his current situation as being on a gap year).

However, this relatively stable set-up did not prevent the group from painting a sombre picture of their immediate neighbourhood, not least even by that member of the group whom we quoted as the epigraph to the article. This participant described their neighbourhood, in a rather emphatic tone, as a place that was tough to live in. This neighbourhood, she explained, was 'a place that has issues and like problems and like bad stuff and things like that'.

Other participants from the focus group were quick to elaborate on this critical view by mentioning a number of issues that cast their community in negative light. Living in this community meant being confronted on a daily basis with problems of substance abuse, corruption, overpopulation, unemployment, crime, drunk driving, alcohol abuse and squatter camps. When asked how they coped with these adverse circumstances, a general response was, 'ah, we are used to it'. This almost boastful explanation suggests that these young people lived in and embodied the spatial challenges of the city (cf. Fuller \& Löw 2017:480), but some of them did this with resilience and without losing hope for the future. This was clearly reflected in the responses to the question about their dreams for the future, which were remarkably similar and often contained elements of a middleclass lifestyle:

'We have dreams! [It] is to finish school, go to university, get everything and then ja ... to have my own company or at least go to IT or Electrical.' (Participant 1)

'I want to finish matric, go to Varsity and get a nice job.' (Participant 2)

'Ja, I know I like I want to be focusing I want to study electricity. Ja, that's what I want to focus on and do electricity.' (Participant 5)

'I want to be a pilot and a soccer star.' (Participant 6)

Although the above quotes represent good examples of the way in which a significant number of young people wanted to remain hopeful about a better future for themselves, the realities of unemployment, a hostile, dangerous environment and drug addiction clearly dominated their everyday 
existence. As a result, these factors also impacted certain participants' own sense of how they felt excluded from opportunities in their immediate environment. We consider the cases of two individual interviewees: Benjamin, a 22-year-old man who grew up in Pretoria Central but completed his schooling in another province, and Calvin, a 25-year-old man who completed high school in Pretoria Central, then spent some years in Polokwane, the capital of the Limpopo province of South Africa, but then returned.

Benjamin decided to return to Pretoria Central because he believed that there were more job opportunities there and rented a place in an informal dwelling. He had some experience with construction work and had previously worked nearby as a temporary contract worker in the construction industry. He was, however, unemployed at the time of the interview and pinned his hopes on a huge government building that was under construction in the area to provide at least some temporary employment opportunities. Yet to his dismay, these were given to 'people from outside' (some of them most probably migrants), thereby taking job opportunities away from young people, which included his own circle of friends: ${ }^{7}$

'I know the majority of the young people ... because we are a whole friendship group moving around here in the location, and we say to one another that these are now the two projects they have going; we apply [for jobs], but we get nothing.'

We could present the case of Calvin as being not much different from that of Benjamin. Having also returned to Pretoria Central in the hope of a better future, he similarly bemoaned the fact that he was now finding himself 'on the street ... looking for a job'. And, in similar manner, he also related his immediate predicament to 'a problem of foreigners'. However, unlike Benjamin, Calvin related this problem more to the way in which the foreigners were directly responsible for the situation of endemic substance abuse in the area (and in South Africa at large). From his perspective, this problem was directly responsible for the destabilisation of his own community and a concurrent lack of job investment, with detrimental consequences for young people.

Besides Calvin, several other participants likewise identified the issue of substance abuse as a major problem plaguing Pretoria Central communities. Yet this included some participants who were also willing to acknowledge their own substance addiction and the way it had a detrimental effect on their life prospects.

We relate as a pre-eminent case the accounts of Queen (30-year-old female), Neo (24-year-old female), Lindiwe (25-year-old female) and Winnie (24-year-old female). These young women were upfront about their substance addiction to Nyaope. They gave evidence of their lives on the streets,

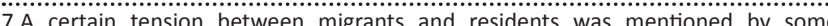
participants, which is indicative of a wider sense of intolerance that simmered participants, which is indicative of a wider sense of intolerance that simmered
under the surface. Over the past decade, this tension has culminated sporadically in xenophobic attacks in certain areas of South Africa (cf. Mahr 2017). with Queen recounting her 8-9 years on the streets, Neo her 7 years on the streets, Lindiwe her untold number of years on the streets and Winnie her 2 years on the streets. Caught in situations characterised by substance abuse, crime, idleness and separation from their own children and family, their futures were, according to their own admission, rather hopeless. This did not exclude expressions of hope against all odds, such as Neo still wanting to 'make something of her life', Lindiwe (who dropped out of school in Grade 10) wanting 'to go back to school' and fix her life, and Winnie wanting to go 'back home' to reconcile with her parents, reunite with her child and get a job. Yet at the same time, these hopeful expressions were countered by pronouncements of despair, such as Queen responding that it was 'too late' to fulfil her many dreams and that she was in fact 'tired of this life'. In similar manner, Winnie also explained that she might not have much of a future unless she stopped smoking Nyaope: 'to be honest, for me I think if I continue to smoke, even twenty years is too long, I can't make it'.

We do not have sufficient space left here to recall in more detail the accounts of our other participants, and can only highlight how their life stories in Pretoria Central seemed to follow similar trajectories to those we have highlighted so far.

Mpho (22-year-old female), Lucky (21-year-old male) and David (23-year-old male) were three of the individual interviewees who had in common the fact that they all migrated from neighbouring countries in search of a better life in Pretoria. However, their moves also similarly took a turn for the worse. Mpho, who wanted to escape her dysfunctional family life in Maseru (Lesotho) recalled how she was now finding herself 'sleeping with other people on the street, all men'. Lucky, who came to South Africa in search of employment opportunities to support his mother back home recollected how he likewise found himself confined to a life on the streets and doing occasional odd jobs such as paid garden work, and David, who in his own words, had been searching 'for greener pastures' was rather upfront about his lonely life on the streets, with a nearby park as his overnight home. He acknowledged that he had basically not only given up 'searching for work', but in fact on life itself: 'ah, I don't have any hope ... It is just I am giving up'.

Our successive focus group interviews with the eight men and the six women offered another glimpse of young people living rather desperate lives in Pretoria Central. Both group interviews were conducted at a central point in one of the neighbourhoods in the area.

The interview with the men turned out to be with a group of men living on the streets who, in the words of one participant, were all 'busy looking for jobs'. Their situation of unemployment appeared to be chronic and, to a large extent, became a topic that dominated the discussion. The only success of these men had been to find casual jobs (like gardening and painting), which could well be explained by their low levels of education and training (ranging from 
indications of having obtained Grade 10 to matriculation to a certificate in Basic Ambulance training). This clearly represented a rather desperate situation for some, as expressed by another participant: 'I'm saying there is no hope here'.

In comparison, the situation of the six women did not seem any better except for the fact that they had, at the time of the interview, all found a temporary haven at a local shelter intended to provide holistic support for women in crisis along with their children. Finding temporary residence in this shelter was perhaps the only reason why they were not likewise forced into a life on the streets. And while they clearly expressed the desire to rise from their current situation, a certain degree of anxiety was also noticeable among participants about achieving this goal within the period they were allowed to stay in the shelter. In the words of one participant:

'Most of us, only if not all of us, we all want to get back on our feet. But sometimes it's not as quickly as we'd hope, you know, because sometimes they will tell you your time is up and you're thinking oh my goodness! I haven't done anything or nothing has come up yet for me. It is a bit stressful.' (Participant, focus group interview with women)

As suggested by our discussion at the start of this section, we also encountered participants who found themselves in relatively more stable and secure environments, which was also reflected in a more hopeful outlook on life. We close this section by pointing to the similar case of the 10 participants from our individual interviews who did not live their lives on the streets of Pretoria Central. They were young people who in most cases still attended various educational institutions, in a few cases even engaged in some form of volunteer work, and, generally speaking, seemed somewhat more upbeat about their life prospects. Yet their vulnerability is reflected in the way in which they were without exception either living in shelters and foster care homes or households headed by single (lone) mothers or siblings.

\section{Perceptions and expectations of faith-based organisations amidst experiences of hardship}

For the large majority of young people interviewed, a discussion about FBOs related directly to the Christian churches, which were the FBOs they knew and many had regular contact with. As a result, churches were the organisations that shaped their perceptions and expectations of FBOs amidst their experiences of hardship.

In some cases, this exposure to FBOs also extended to the operational work and activities of particularly one Christian faith-based NGO.

One of the strongest impressions that emerged from the interviews was the rather conventional perceptions and expectations the young people had of churches generally speaking, but also more specifically of the church or churches they had direct contact with. Related to such perceptions and expectations, we in fact encountered no young person who seemed to be openly atheist or a non-believer, even if he or she appeared to be critical of and less devoted to the Christian church and its activities. Instead, we encountered a large majority of young people who seemed highly religious and committed to their faith, openly willing to confess their belief in God and Christ as the source of their strength and preservation. This noticeably included an acknowledgement that praying to God was an important religious practice in their lives.

A few striking examples suffice to illustrate the point. Peter, an 18-year-old male from Salvokop, admitted that he believed it was Christ's presence in his life that made him to survive during all the years of migrating from country to country. Thabeo, a 23-year-old female temporarily living in a shelter for women in crisis, in turn stated that she believed it was only God who protected her from being raped when she was forced to sleep under a bridge with other homeless people after arriving in Pretoria. And Da Silva, a 25-year-old male living a lonely life on the streets of Pretoria, similarly acknowledged that God was in fact his 'only friend'. But in addition to these examples, we could also quote the following responses as telling testimonies by some participants of how their faith provided certainty and solace amidst their lives of hardship:

'Ja me I believe in God, you see. Because God is the one who is protecting me every day. Like he is the one who stand up, is the one who protects me and give me some mentality to do something. He is the one who teaches me how to go somewhere.' (Lucky)

'No, I can't blame God, sir. He knew me before I was even been found. He knew me, it's who I am.' (Wisdom, 22-year-old male)

'I think that is one thing that has kept me from going astray ... I have a very strong faith and have always been a church-going person and I've always looked up to God for comfort and everything. So it's not just now, it's been like that for me.' (Phalisa, 19-year-old female)

As well reflected in Phalisa's direct response, it therefore came as no surprise that several participants made a direct connection between their faith and the importance of attending church. While there were also those participants who reported that they attended church sporadically or not at all, others seemed fairly devoted churchgoers. For instance, such devotion is reflected quite emphatically in Phalisa's ongoing discussion about her faith. She had no hesitation in identifying the church as the organisation that played the most important role in her life. In this respect, she went on to state that she had in fact never been to a nightclub and attended church on Sundays and Wednesdays. And when asked why she attended this specific church, which was some distance from her home, she replied:

'Because I love it there. When I got there I got a sense of belonging. I felt like there's God. I felt like I'm comforted there, I am at peace. I just love it. I do not see myself in any other church other than the one that I'm in right now.' 
For Phalisa, and several other young people interviewed, going to church thus provided the opportunity to strengthen their faith and experience fellowship with God and fellow believers through religious activities that included worshipping, praying, listening to sermons and singing. These were activities for which this group of interviewees appreciated the churches and that even led some of them to attend church as frequently as three to four times a week. In other words, these activities framed the young people's expectations of the church, to the extent that they seemed to expect very little if anything from the church outside these activities. This is reflected, for instance, in the response from Peter that the sole reason he attended the church was 'for worship'. His further response suggested that it did not really matter to him that members of the particular church had to date not helped him 'with anything' tangible. However, what he did expect and regarded as non-negotiable was to attend a church where worshipping God takes centrestage:

'As long as they uplift the name of Christ and they uplift God. That's all I am concerned about.'

Our case study results thus suggest that the social life of a number of young people revolved around the activities that their churches provided. Besides their appreciation of churches as places of worship, there were among the participants also those who expressed a somewhat broader social appreciation. Thus, attending church two, three or even four times a week meant that these young people were not only enthusiastic participants in the Sunday worship services and weekly prayer and praise and worship meetings. In a similar enthusiastic manner, some individuals also alluded to their participation in weekly choir practices, drama sessions, DVD evenings and events that extended beyond weekly gatherings in the form of youth camps and spiritual conferences. The following extracts give an insight into how some of these activities were appreciated by our interviewees for their social (capital) value:

' $[M]$ ostly everyone in the Sunday School, we are in the choir at church and then we can go places. Like we went to Bloemfontein. The bishop was there and then we went to, I don't know, I forgot the place, it was somewhere next to, before Botswana.' (Leto, 17-year-old female)

'Ja, spiritual conferences ... [We] visit some of the sisters' houses, they come and visit us, they chat with us, we get together, we make some lunches here in the house, especially the youth come, and their pastors ... and they do come, just stay with us, they sleep over, we read and we also visit, we get together.' (Josephine, 21-year-old female)

Responses by a number of participants pointed to a strong perception that going to church and participating in church activities arguably provided the best safeguard against the dangers of the unsafe world around them. Such confidence in the churches is reflected, for instance, in Peter's comment that he found the church to be a place of 'relaxation'. Petrus, a 21-year-old male from Salvokop, responded in similar manner that he saw the churches as having the ability to take young people 'out from the street', from activities that young people such as himself were '[not] supposed to be doing'. This belief in the church also reverberated in Phalisa's affirmation that it was the church that kept her 'from going astray or following peer pressure and being influenced', as well as, similarly, in a participant from the focus group interview with male participants who stated that it was within the power of the churches to help young people to 'leave the alcohol and drugs'. Clearly, then, for these young people, the churches were nothing less than being a potential and actual moral guide and force in their lives.

It should be conceded that such positive perceptions and expectations of the churches predominantly came from those young people whom we profiled as experiencing a relatively stable set-up. In contrast, however, a somewhat different picture emerges when we shift the focus to those interviewees whom we identified as on the receiving end of even harsher conditions through their lives on the streets of Pretoria Central. While members of this group almost without exception confirmed their belief in God, and while a good number of participants suggested through their responses that they belonged to the above-mentioned group of devoted churchgoers, it is among this group, both through the individual and focus group interviews, that we also encountered those who confirmed their lack of regular or any church attendance.

We do not want to overlook the possibility that feelings of shame and a loss of expectation that the churches could make a difference in their desperate situations were direct but unspoken causes of apathy, or at least a lack of enthusiasm, towards the churches. At the same time, however, we could importantly also allude to a more critical disposition towards the churches among members of this group. Prompted in particular by the questions of whether the church did anything for them, could do anything for them or could do more for them or help them better, some participants remained rather vague or indifferent in their respective responses, while others were more outspokenly critical. The following responses, for instance, give evidence of certain individuals' discontent about what they experienced as church people's insensitive attitudes towards their real-life needs:

'I don't think so. Because I remember one day I asked Katlego about those things. She said to me I am supposed to stand up myself. He says 'stand up yourself and go look for a job'. Me I said to them, I said to them straight, I said: 'Ah, Katlego, you are $[a]$ Christian'.' (Lucky)

'It just feels for me as if the churches are more concerned with making money than to serve the Lord ... They are not doing much for the youth as far I know.' (Benjamin; translation from Afrikaans)

'When we ask about jobs, they just pray for you.' (Participant, focus group interview with men)

In addition to the above responses, some of the most stringent views emanated from our interview with the group of six women already introduced earlier in the discussion as temporary residents of a local shelter. 
The duration that they were allowed to stay in the shelter was 3 months, on condition that they had to take part in all the activities that were offered at the shelter by volunteers. If they wanted to stay longer than 3 months, their participation in the activities became a major consideration in granting them more time to stay there. At the time of our interview, however, many of the women were at the end of their 3 months cycle and agitated about their future as a result. Cynical views such as the following were expressed:

'Ja, the churches. I think churches are not doing anything for ... I don't know if they are, but they're really not doing anything. Those churches come in and give us like soaps and toiletries, I mean we have lots and lots, our bags are full of toiletries.' (Participant, focus group interview with women)

'We actually need someone like a company that say 'look I'm here, I am looking for skilled people, I am looking for five people', for example. 'What do you have, what can you do?' And then they employ us maybe for a year or two just to ... you know. Instead of people ... I appreciate the toiletries, but when your three month is up, you leave with the bag of toiletries.' (Participant, focus group interview with women)

Importantly, then, these statements came from a group of young people that fitted a somewhat different profile - older women who had children and may have been employed in the past. They had been living independent lives previously and did not regard exposure to a variety of activities as a current need. And as the above quotes suggest, they also did not appreciate being flooded by the many handouts from church volunteers. Essentially, their case differed from the other young people's cases in the sense that it did not entail their entering or exposure to any church space, but church members who entered their living space (i.e. the temporary shelter where they found themselves). For the women, however, this reverse situation turned out to be nothing short of being intrusive and undermining their dignity. From their perspective, it represented an outreach that neglected their real needs and exposed the volunteer work simply as an act that made the volunteers feel better about themselves. In this regard, it was even observed among the group that when volunteers prayed for or spoke to them living in the shelter, you had 'to look depressed ... like shame and stuff' (Participant, focus group interview with women). In other words, the women felt that because the volunteers were performing as do-gooders, they as recipients also had to perform as being thankful and/or shameful.

However, a complete picture from our interviews about the young people's perceptions and expectations of the churches suggests that the churches still functioned as perhaps the most important institution on the ground meeting the most basic survival needs of those exposed to a life on the streets. A perception cutting across many interviews with the young people who fell in this group, including those who expressed more critical views, is one of ongoing dependence on the churches to provide them with basic facilities as well as food, clothes and other items for their everyday survival. But even more, among this group, we also encountered a very few that seemed steadfast in their higher expectations of the church to serve as a bridge out of their present desperate situation. We close the discussion in this section with the story of a young couple that reflected such expectations.

Solly (22-year-old male) and Joyce (18-year-old female) hailed from the Eastern Cape province of South Africa, where they had met. A decision taken by Solly to travel to Gauteng in pursuit of employment unfortunately had unforeseen consequences, as not only did he fail to secure a regular income, but also became addicted to Nyaope. On her part, however, Joyce decided to follow him a few months later in what sounded almost like a romantic daze as even Solly tried to discourage her to join him as he was living on the streets. Joyce's siblings and cousins were always against their relationship, but this seemingly made her even more determined to follow Solly. They were now both living on the streets, while Joyce was 4 months pregnant with Solly's child at the time of the interview. They experienced street life as harsh and had at least one violent encounter when Joyce was almost raped. They spent most of their day hustling for money in order to get enough to eat and to support Solly's Nyaope addiction. Now that Joyce was pregnant, health concerns and nutritious food were also becoming more important. Both of them were raised by grandparents who had passed away, while their parents had never made any real tangible contribution to their upbringing. Their living siblings and cousins were also not in a position to help them financially, but still the small town in the Eastern Cape from which they had wanted to escape was now described as their 'home' that they wanted to return to. And to achieve this, their main, if not last, hope against all the odds was an appeal to a particular church to help them with transport money:

'You see we are going there [attending a church service], we thought that it is a church; they will still pay for us. They will help us to go back home, you see, if we are going there. So, when we are going there, they don't want to help us. They are telling us that we are 'nyaope people'. Yes we do smoke nyaope but I will leave nyaope when I go back home. We don't want money; we want them to help us to buy a ticket for us to go home.' (Solly)

\section{Faith-based organisations meeting basic survival needs}

Based on the discussion above, we could so far lay claim to a fairly well-developed picture about the extent to which FBOs touched the lives of the young people whom we had interviewed. This is a picture of local churches playing an important, if not indispensable, role in meeting a noticeable number of young people's needs on an existential and social level. For those young people, certain local churches represented places par excellence to strengthen their faith through direct contact with God and fellow-believers, and to experience a broader sense of belonging and socialising through a wider range of activities. To this extent, churches also functioned as an important moral compass for several 
young people, safeguarding them from the dangers of their surrounding world and thereby enhancing their sense of moral security and safety.

However, the discussion also presented a picture of a number of young people for whom the churches did not carry the same existential and social significance. To this group belonged a number of individuals whose harsh lives on the streets of Pretoria Central and in temporary shelters coincided with an aloofness and in certain cases even a more critical attitude towards the churches and their activities. But while this could be considered as an important image, such aloofness and critical attitude did not imply a complete distance from or lack of dependence on the churches. Instead, our findings revealed that it was especially members of this group of highly vulnerable young people who appeared to be most dependent on local churches - and in certain cases also the faith-based NGO mentioned at the start of the previous section - to meet their most basic survival needs.

Thus, despite the aloofness and critical attitude of some, for participants from the group of highly vulnerable young people, FBOs in the form of local churches and the mentioned faith-based NGO represented the logical first, if not only stop, to meet their basic needs for survival in Pretoria Central. This sense of dependence was, for instance, acknowledged by Mpho, when she stated the reason why she frequently visited a particular local church: 'I come to [the] Night Church because I don't have a place to go'. For Mpho, this particular church provided a temporary escape from her life on the streets. It seemed to have multiple meanings for her, as it constituted a place where she could engage in recreational activities such as 'chess and knitting', could even make herself useful by sweeping the church hall and pavement corner where she slept with others, and, not least, could find food and clothing to meet her basic subsistence needs.

'They help with clothes for women and men, [and the] pastor also gives food.' (Mpho)

We find in Mpho's account a meaningful description of what seemed to be a situation of dependence shared by several other participants. For these young people, churches and faith-based facilities clearly offered the only known and visible places where they could find free food, clothes, shelter and facilities to bath, shower and keep their meagre belongings. In a significant way, this was also recognised by those participants who adopted a more critical attitude towards the churches or people in the church. We could, for instance, return to the case of Lucky and the focus group of six women who, despite their criticisms, had the following to say about how they benefited from their relationship, respectively, with a certain church and the residential (shelter) facility:

'Here, I like because also sometimes they give us water to bath, you see. And then they give us like a lock to keep your clothes safe. Ja, and then tea, they give us like in this one ... It's life. It's life.' (Lucky)
'[H]ere you actually stay for free. You actually don't worry about the basic stuff like food, shelter, where to bath, where your kids are going because my kid attends the day care and I pay only R50 while others pay more than that ... And then we are also able to go out there and find jobs because it is easier if you are here in town than being away in the location [township].' (Participant, focus group interview with women)

These were common refrains also reverberating in the responses of several other participants. However, while these young people were in some instances simply recipients of basic subsistence services, in other instances such services were also accompanied by religious instruction. This reinforced the idea that some participants may have used religion in an instrumentalised fashion as a means to receiving something tangible in return. For example, we witnessed prior to one of our interviews how the recipients of bread and tea all had to listen to a religious sermon before food was distributed in a public park. Furthermore, certain responses also suggested that receiving food not only served as a prime motivation to attend church, but even that religious instruction or services might simply have been tolerated or used in order to receive food:

'When I go to church maybe it's where we get food after the church.' (Winnie)

'You see, these churches they play a special $[$ role], the one $[s]$ who provide food, food, food, especially food.' (Luke, 21-year-old male)

Be that as it may, a predominant picture thus emerging from our research is one of FBOs - local churches but noticeably also a prominent local faith-based NGO - playing an indispensable role in meeting the basic survival needs of several of the young people whom we interviewed. Yet at the same time, this could also be depicted as mainly an unchanging picture. At least when captured from the perspective of the young people interviewed, it is a picture of the same FBOs showing little capacity to transcend a mode of social engagement that goes beyond meeting the survival needs of severely marginalised young people within their local contexts.

It becomes important to note, however, that this picture changes somewhat when we take into account the interviews that we conducted with the resource persons alluded to earlier. From our interviews with clergy and FBO workers (which included a focus group of five youth workers), we not only obtained glimpses of a more self-critical attitude but also noble ideals and statements about FBOs playing a more profound role as change agents in the lives of marginalised youths. This does not imply that a number of these resource persons did not still value the traditional roles of their own FBOs in meeting the immediate survival and spiritual needs of homeless young people. At the same time, however, there were among the resource persons also some who acknowledged that such FBO engagement fell short of addressing more deeply rooted social challenges faced by young people on the streets. For instance, we could present the case of Alan, a minister of a prominent mainline church in 
Pretoria Central, who alluded to the inadequacy of the 'relief work' of his own congregation in the wake of the epidemic nature of drug addiction among young people in Pretoria Central:

'People find it easier in their participation ... to say how much do you need you know, get it done rather than be part of what needs to be done. So it is easier to do relief work amongst the homeless because we are given the money than to tackle the issue of Nyaope amongst the young people who are on the streets. In my own discernment for ministry ... I am drawn more and more to this scourge of Nyaope drug abuse in the city, substance abuse because it destroys and there is very little response from [the] state or anybody.

Alan was clearly a compassionate clergyman sensitive to the social sufferings and challenges reflected by the surrounding community. While cognisant of the limitations of his congregation's involvement in the lives of homeless young people, he nevertheless took pride in what his congregation was offering these young people in the form of various services that included a clothes bank, ablution facilities, assistance at the Department of Home Affairs and meals. Moreover, as head minister of a 'cathedral congregation' that attracted a substantial group of more affluent members from outside Pretoria Central, he took special pride in the way in which his congregation had managed to incorporate the homeless (and by implication a substantial number of young people from the streets) into the life of the congregation. For Alan, this was an achievement that could be celebrated as a step towards social cohesion between the 'haves' and the 'have-nots', at least within the immediate confines of his own congregation. In his own words:

'So it was a huge coup to get the homeless to be accepted and be part of this ... Like, for example, when we have tea it is amazing on a Sunday, at about seven-thirty, that there are homeless people who come to this service because there is tea afterwards. Now when I started here and noticed this, they are not in the service but once the service is out they have tea with the congregation, so we started befriending them and in the end encouraged them to be in the services. Now they are in the service and it is amazing to see these guys [homeless people and affluent members] talking with each other after the service and these guys dress up for the service.'

While space limitation does not allow us to elaborate on the responses of the other resource persons (clergy and FBO workers) whom we interviewed, it suffices to say that they likewise testified about an honest desire for a more profound involvement in the lives of marginalised young people. This is reflected in statements of a more visionary and idealistic nature, such as by Mary, who spoke passionately about the existing entrepreneurship programme of her organisation the faith-based NGO mentioned frequently in this article to '(b)ecome more viable in ... [the] city, produce more entrepreneurs, create more jobs'. But it also reflected in statements by a number of resource persons testifying about programme initiatives in their respective organisational milieus that were seeking to make a transformative difference in the lives of marginalised young people. This included reference to advocacy work, a Youth Leadership Academy, a sports programme, an HIV and AIDS programme, a Compassion Centre focused on community theatre and community art and an educational centre.

\section{Are the faith-based organisations making a difference? Concluding observations}

Our aim in this article was to give an account of the way in and the extent to which FBOs were a reality in the lives of a selection of young people in Pretoria Central, our case study area. To this end, the discussion began by giving an account of the selected individuals' experience of Pretoria Central and the varying mental dispositions of hope and despair resulting from their experience. Our findings revealed that for the selected individuals, Pretoria Central had turned out to be a place of considerable hardship. This played out through their experiences of a life on the streets and in temporary shelters, and also of finding their way through the many social issues plaguing the communities of Pretoria Central.

Our findings furthermore testified that FBOs - not only churches but also a prominent faith-based NGO - were in fact in one way or another playing a role in the lives of most of the selected young people. In the case of a large majority of the participants, personal faith and belief in God seemed to have played an important existential role and it is among this group that some also seemed to have been devoted churchgoers, finding meaning and purpose in the worship and social activities offered through the churches. Importantly, however, our research revealed that these kinds of positive experiences were not shared by everyone. A number of participants displayed indifferent attitudes towards the churches and their activities, while some were also more outspokenly critical of the churches for not providing the type of support they felt they required. For these participants, their criticisms were often based on a broader sentiment of frustration with their circumstances and disillusionment at what the future might hold. At the same time, however, one of the important findings was that the criticisms raised did not lessen the dependence of the same young people on local churches and other FBO structures to meet their most basic needs for survival.

For these young people, who belonged to the most vulnerable and disadvantaged among the selected individuals, it in fact seemed to be a case of those churches and FBO structures serving as the only available institutional support to meet their needs.

Faith-based organisations, then, could rightly be appreciated as an important reality in the lives of marginalised young people in Pretoria Central. Yet, when asking ourselves the question to what extent the same FBOs made a more decisive difference by being instrumental in addressing the marginalised situation in which our young interviewees found themselves, we need 
to conclude on a sober note. We indeed find it difficult to draw a positive correlation between those progressive elements of social cohesion that were identified in the YOMA project (Angell \& De Beer 2019) and our own case study findings. Instead, what we gained from our research was exposure to a group of young people so marginalised in relation to the wider society that their prospects of sharing in the fruits of social cohesion - as, for instance, defined by the notions of belonging, inclusion, recognition and participation - seem hard to imagine. This turned out to be a context where the prospects of getting access to the necessary support services of the state seemed rather slim for marginalised young people, such as those whom we encountered. And it is in this context that churches and other faith-based structures were trying to compensate for the lack of state intervention by meeting young people's basic survival needs in addition to providing more traditional faith-related activities.

Finally, then, when using our concluding perspective as a lens to answer our guiding question whether the FBOs are making a difference in the lives of young people at the margins in Pretoria Central, the answer seems in many ways to be a negative one. In Pretoria Central, the FBOs as a collective seem to make very little difference in the conditions of seemingly permanent structural exclusion in which many young people find themselves. And yet, when giving this concluding answer, we do not want to disregard the role the churches in particular are playing in offering worship and social activities through which at least some young people experience a sense of belonging and existential meaning. Furthermore, and of no lesser importance to acknowledge, we could allude to our interviews with resource persons that gave evidence of what also appear to be honest desires and efforts especially among FBOs of the NGO type to initiate activities that could potentially strengthen the FBO contribution to marginalised young people's experience of social cohesion.

\section{Acknowledgements}

All fieldwork and data analysis were undertaken by the authors. We wish to thank various FBO personnel for their support and access to information. Due to confidentiality agreements, we thank them anonymously.

\section{Competing interests}

The authors declare that they have no financial or personal relationship(s) that may have inappropriately influenced them in writing this article.

\section{Authors' contributions}

I.S. and M.R. conducted the fieldwork. I.S., M.R. and S.d.B. all contributed to the writing of the article. I.S. acted as the lead author, was responsible for all revisions and prepared the article for submission.

\section{Ethical consideration}

Ethical clearance for this study was obtained from the University of South Africa. For the purpose of ethical clearance, persons interviewed in this research or persons who in any way became involved as 'co-researchers' as a result of their interaction with the authors remain anonymous. The authors declare that everything possible has been done to maintain confidentiality. Pseudonyms are used in all instances to refer to the interviewees.

\section{Funding information}

This research received funding support from the College of Human Sciences at the University of South Africa and the National Research Foundation (under grant number 85728).

\section{Data availability statement}

All new data generated are kept confidential in the care of the authors according to standard ethical guidelines.

\section{Disclaimer}

The views and opinions expressed in this article are those of the authors and do not necessarily reflect the official policy or position of any affiliated agency of the authors.

\section{References}

Angell, O.H. \& De Beer, S., 2019, 'Social cohesion: Critical theoretical exploration of a concept', Unpublished chapter submitted for the YOMA project manuscript in
preparation, Stuck in the margins? Young people and faith-based organisations in South African and Nordic localities.

Babbie, E., 2013, The practice of social research, 13th edn., Wadsworth, Belmont, CA.

Clarke, G. \& Jennings, M., 2008, 'Introduction', in G. Clarke \& M. Jennings (eds.), Development, civil society and faith-based organizations: Bridging the sacred and the secular, pp. 1-16, Palgrave McMillan, Basingstoke.

De Beer, S.F. \& Vally, R., 2015, 'Pathways out of homelessness', Research report, University of Pretoria, Pretoria, viewed 16 April 2019, from https://www.up.ac.za/ media/shared/249/ZP_Files/homelessness-report-2015.zp70613.pdf.

De Beer, S.F. \& Vally, R., 2017, '(Finding) pathways out of homelessness: An engaged, trans-disciplinary collaborative in the City of Tshwane', Development Southern Africa 34(4), 385-398. https://doi.org/10.1080/0376835X.2017.1319261

De Beer, S.F. \& Smith, R.D., 2019, 'Religious innovation and competition amidst urban social change: Pretoria case study,' Journal for the Study of the Religions of Africa and its Diaspora 5(1), 104-121.

De Lannoy A., 2017, 'The UCT poverty and inequality initiative's youth explorer: Understanding youth well-being at the small area level', Paper prepared for the Centre for Development and Enterprise's Youth Unemployment Project, August 2017, viewed 16 April 2019, from https://www.cde.org.za/unemployment/wpcontent/uploads/2016/08/The-UCT-Poverty-and-Inequality-Initiative\%E2\% $80 \% 99$ s-Youth-Explorer-Understanding-Youth-Well-being-at-the-Small-AreaLevel-Adrian-De-Lannoy.pdf.

Fuller, M.G. \& Löw, M., 2017, 'Introduction: An invitation to spatial sociology', Current Sociology Monograph 65(4), 469-491. https://doi.org/10.1177/0011392117697461

Gauteng City-Region Observatory, n.d., The Gauteng City-Region, viewed 16 April 2019, from https://www.gcro.ac.za/.

Grelotti, D.J., Closson, E.F., Smit, J.A., Mabude, Z., Matthews, L.T. \& Safren, S.A., 2014 'Whoonga: Potential recreational use of HIV antiretroviral medication in South Africa', AIDS and Behavior 18(3), 511-518. https://doi.org/10.1007/s10461-0130575-0

Mahr, K., 2017, 'Attacks on migrants point to rising tension in South Africa', Financial Times, 06 March, viewed 04 June 2019, from https://www.ft.com/content/ 15212cba-024d-11e7-aa5b-6bb07f5c8e12.

Mkansi, M.P., 2012, 'The policing of sex workers in Sunnyside', Unpublished M Tech thesis, University of South Africa, Pretoria, viewed 16 April 2019, from https://hdl. handle.net/10500/11987.

Moloko-Phiri, S.S., Mogale, R.S. \& Hugo, J., 2017, '“A shelter is not a home”: Voices of homeless women in the City of Tshwane', Development Southern Africa 34(4), 439-449. https://doi.org/10.1080/0376835X.2017.1318048

Neuman, W.L., 2003, Social research methods, 5th edn., Pearson, Boston, MA. 
PEN, n.d., Ignite change, nurture individuals, heal communities, viewed 15 April 2019, from https://www.pen.org.za

People Upliftment Programme (POPUP), n.d., Transforming lives, uplifting individuals, impacting their world, viewed 15 April 2019, from https://www.popup.co.za.

Rabe, M., Swart, I. \& De Beer, S.F., 2019, 'Hope for a better future: Young people's (im) mobility in Pretoria Central, South Africa', in H. Cuervo \& A. Miranda (eds.), Youth, inequality and social change in the Global South, Perspectives on children and young people, vol. 6, pp. 163-178, Springer, Singapore. https://doi.org/10.1007/ 978-981-13-3750-5_11

Ribbens, M. \& De Beer, S.F., 2017, 'Churches claiming a right to the city? Lived urbanisms in the City of Tshwane', HTS Teologiese Studies/Theological Studies 73(3), a4690. https://doi.org/10.4102/hts.v73i3.4690

Sediba Hope Medical Centre, n.d., Sediba Hope Medical Centre, viewed 15 April 2019, from https://www.sedibamedical.co.za/.

Statistics South Africa (StatsSA), 2011, Census 2011, viewed 13 April 2019, from https://www.statssa.gov.za/publications/P03014/P030142011.pdf
Statistics South Africa (StatsSA), n.d., City of Tshwane, viewed 13 April 2019, from https://www.statssa.gov.za/?page_id=1021\&id=573city-of-tshwane-municipality.

Swart, I., 2013, 'Youth at the margins: Introducing a new research initiative in an ongoing south-north collaboration in the context of international diaconia', Diaconia: Journal for the Study of Christian Social Practice 4(1), 2-26. https://doi. org/10.13109/diac.2013.4.1.2

Swart, l., 2018, 'Youth marginalisation as a faith-based concern in contemporary South African society: Introducing a research contribution', HTS Teologiese Studies/ Theological Studies 74(3), a5253. https://doi.org/ 10.4102/hts.v74i3.5253

Tshwane Leadership Foundation, n.d., Tshwane Leadership Foundation, viewed 15 April 2019, from https://www.tlf.org.za.

Wazimap, n.d., City of Tshwane, viewed 13 April 2019, from https://wazimap.co.za/ profiles/municipality-TSH-city-of-tshwane/.

Yeast City Housing, n.d., Building lives, building communities, building homes together, viewed 15 April 2019, from https://www.ych.org.za/home. 